\title{
Wspomnienie o księdzu Jerzym Chmielu jako znawcy judaizmu biblijnego
}

\author{
Maria Kantor
}

Kraków

maria_kantor@hotmail.com

Zazwyczaj każdy u progu swej kariery pragnie mieć kogoś, kogo mógłby nazwać swoim nauczycielem, który byłby dla niego przykładem, na którego dobrą radę mógłby zawsze liczyć. Mówiąc krótko, mieć swojego Mistrza. W swej krótkiej karierze naukowej (1989-1996) miałam wielkie szczęście, bo moim Mistrzem był ksiądz profesor Jerzy Chmiel, w którego szerokim spektrum aktywności pierwsze miejsce zajmowała Biblia.

Księdza Profesora poznałam w październiku 1987 roku, gdy byłam na czwartym roku studium teologii dla świeckich na Papieskiej Akademii Teologicznej w Krakowie. Traf chciał (po latach uznałam to za zrządzenie Opatrzności), że zapisałam się na jego seminarium z hermeneutyki biblijnej i judaistyki. Pamiętam pierwsze zajęcia seminaryjne w budynku przy ul. Szujskiego. Uczestniczyło w nich kilku kleryków, studentów teologii, i ja - osoba świecka, a w dodatku kobieta. Ksiądz Profesor przedstawił mnie jako absolwentkę Uniwersytetu Jagiellońskiego, która zajmuje się poezją biblijną. Rzeczywiście w Instytucie Filologii Angielskiej moja praca magisterska Parallelism in the Psalms - The Authorized Version of the Bible (w ramach seminarium magisterskiego Stylistyka lingwistyczna) była analizą biblijnych struktur poetyckich. Pamiętam też, że Ksiądz Profesor wyraził przekonanie, że moja obecność na seminarium z hermeneutyki biblijnej i judaistyki zaowocuje wspaniałą pracą magisterską. To przekonanie i wiara w potencjał każdego studenta były charakterystyczne dla księdza profesora Chmiela. Zawsze zachęcał do podejmowania dalszych studiów i badań naukowych, przekazując jakby swoje pozytywne podejście i wiarę w możliwości każdego człowieka. 
Mnie też zachęcił do uczęszczania na zajęcia z języka hebrajskiego prowadzone przez niego w krakowskim seminarium duchownym, a potem do kontynuowania nauki na studiach licencjacko-doktoranckich na Papieskiej Akademii Teologicznej w Krakowie. Tak zaczęła się moja przygoda z hermeneutyką biblijną i judaistyką pod kierunkiem ich wielkiego znawcy i pasjonata. Ksiądz Chmiel był promotorem mojej pracy magisterskiej zatytułowanej Zjawisko paralelizmu w poezji starohebrajskiej na przykładzie Ps 119. Analiza filologiczno-egzegetyczna (uznanej za licencjacką) oraz doktorskiej pt. Struktury dośrodkowe i odśrodkowe $w$ poezji biblijnej na przykładzie psalmów pielgrzymów (Ps 120-134).

Pierwszym elementem tej przygody była nauka hebrajszczyzny biblijnej. Uczęszczając na wykłady prowadzone przez księdza Chmiela, odkrywałam rzeczywistość przedstawioną w czasach Starego i Nowego Testamentu - judaizm biblijny. Ksiądz Profesor, ucząc języka hebrajskiego, opisywał środowisko, w którym ten język był używany. Wprowadzając alfabet, wyjaśniał każdą literę. Podawał różne słowa i zwroty hebrajskie: mazel tov, kol tov, toda raba. Na jednych z pierwszych wykładów napisał hebrajskie słowa najstarszego credo monoteistycznego. Wprowadzał elementy semantyki biblijnej: aramejskie słowa w Nowym Testamencie, wyjaśniał imiona hebrajskie, podając ich odpowiedniki w Septuagincie.

Wprowadzając zagadnienie czasownika hebrajskiego i czasów gramatycznych, cytował z rozdziału JEST, czyli historia jednego przekładu książki pt. Krąg biblijny Romana Brandstaettera:

Czasownik hebrajski jest bezczasowy. [...] Jahwe nie był i nie będzie. Jahwe jest. Jest, który jest. [...] Lud Izraela pisał i mówił „był”, ale to „był” przeżywał w swojej świadomości jako ,jest”.

Ową bezczasowość czasownika hebrajskiego przedstawiał Ksiądz Profesor w formie wykresu, który nazywał „zegarem czasów hebrajskich”: schemat qatal = waiqtol $\mid$ iqtol = weqatal, a pośrodku linia $\mathrm{z}$ tetragramem. Mówił: „Czymże więc jest czas teraźniejszy? To, co powiedziałem, należy do przeszłości, a to, co powiem - do przyszłości. Tylko 
Bóg jest”. Innym jego schematem była reguła znajdowania tematu czasownika, która według Księdza Profesora była pewna w 88,6 proc.

Zajęcia z hebrajskiego kończyły się czytaniem i analizą pierwszego rozdziału Księgi Rodzaju, w trakcie których były częste odwołania do słów greckich i łacińskich oraz porównania z tekstem Septuaginty i Wulgaty. Ksiądz Profesor przekazywał też liczne uwagi co do sposobu tłumaczenia tekstu hebrajskiego na język polski. Odwoływał się do literatury rabinicznej, mówiąc na przykład o zapisie słowa „Jezus” w Talmudzie. Ponadto wyjaśniał elementy judaizmu, między innymi koszerność, chleb niekwaszony. Wprowadzał w język jidisz, podając zasady zapisu głosek niemieckich i polskich w tym języku, a jako ciekawostkę objaśniał nazwę „Kraków” w jidisz.

Ksiądz Chmiel był charyzmatycznym wykładowcą. Sposób prowadzenia przez niego wykładów był bardzo interesujący. Umiał mówić pięknie, tak że słuchało się go z wielką przyjemnością. Posiadł sztukę polegającą na zjednywaniu sobie słuchaczy, porywaniu ich w zagadnienia biblijne. Treść jego wykładów łatwo zapadała w pamięć. Na zajęciach przebijała z jego wypowiedzi fascynacja tym, czym się zajmował w pracy naukowej, która tak inspirująco działała na studentów. Był też prawdziwym opowiadaczem, gawędziarzem, jakich dziś już mało. Niejednokrotnie przeplatał swoje wykłady anegdotami i dowcipami żydowskimi.

Swoją wiedzę o judaizmie biblijnym Ksiądz Profesor przekazywał na seminarium $\mathrm{z}$ hermeneutyki biblijnej i judaistyki oraz na konwersatoriach: Symbolika judeochrześcijańska oraz Homilia judeochrześcijańska i jej nowotestamentalny zapis prowadzonych w małej salce nr 025 w budynku przy ul. Franciszkańskiej 1 wypełnionej po brzegi książkami, mapami, ilustracjami, rycinami, obrazami i judaikami. Jedna ze znajdujących się w tej sali szaf miała dumny napis: „Zbiory archeologii biblijnej”, a na jej półkach znajdowały się lampki oliwne, mezuzy, menory, dzbany, kamienie z Masady, Qumran i Morza Martwego, ozdoby, zasuszone rośliny z Ziemi Świętej, figurki, przypalone fragmenty Tory. Druga szafa zawierała judaika: zwoje pergaminowe, szofar, filakterie, jad do czytania Tory, starożytną procę, mirrę, kadzidło, ozdobne pokrowce na Torę, wzory monet z czasów Jezusa. Ponadto na innych półkach były fragmenty macew i figurki bożków egipskich, a w szufladach 
mikrofilmy, zdjęcia, filmy wideo oraz bogate zbiory syndonologiczne. Przy biurku Księdza Profesora stała, jak gdyby czuwając nad wszystkim, spora figura Mojżesza. Wszystkie eksponaty odzwierciedlały kręgi tematyczne zainteresowań księdza Chmiela. Dodać należy, iż salkę wypełniała woń drzewa sandałowego i cedru, gdyż Ksiądz profesor zwykł palić kadzidełka - patyczki zapachowe.

W trakcie seminarium hermeneutyki biblijnej omawiał metody badawcze w egzegezie, wyjaśniał, czym jest transliteracja, a czym transkrypcja. Szczególną uwagę zwracał na analizę struktury tekstu i metody lingwistyczne, podkreślając słynną łacińską sekwencję Bengela: Te totum applica ad textum; rem totam applica ad te - siebie samego zastosuj do tekstu, a rzecz całą zastosuj do siebie.

Uczestniczyłam w konwersatorium nt. symboliki judeochrześcijańskiej. Ksiądz Profesor podkreślał, że pierwszą podstawą symboliki jest pismo: alfabet hebrajski, grecki i łaciński, objaśniając znaczenie każdej litery. Jako przykład podawał opowiadanie o ukazaniu się Jezusa nad Morzem Tyberiadzkim (J 21): przekaz oparty na symbolice alfabetu greckiego i hebrajskiego. Omawiał symbolikę hebrajskich cyfr oraz symbolikę pieczęci (porównanie Ez 9, Ef 1, Ap 7 - pieczętowanie na czołach). Przedstawiał rodzaje kryptografii w symbolice judeochrześcijańskiej:

1) użycie innego języka: mieszane napisy hebrajskie, greckie i łacińskie, pisanie imienia Jahwe alfabetem fenickim, zmianę szyku liter w znanych wyrazach;

2) skróty i brahygrafia - pisanie w skrótach;

3) tajemnice wiary (INP, FI, RE, NA).

Interesująco omawiał symbolikę w recytacji tekstu (recytacja melodyjna i reguły śpiewania), jak również symbolikę imion i nazw biblijnych czy imion teoforycznych: hebrajskich, aramejskich (Marta, Kefa) i greckich.

Innym zagadnieniem, które go interesowało, była symbolika toralna: elementy związane z Torą; symbolika świątyni jerozolimskiej, symbolika arki; symbolika architektury świątyni, symbolika miasta świętego czy symbolika synagogi. Kolejnym tematem była symbolika antropologiczna (narodziny dziecka, amulety); symbolika obrzezania, symbolika szkoły oraz symbolika uświęcania dnia płynąca z przymierza, która przypominała o zobowiązaniach wobec Boga. 
Niezmiernie intrygującymi były zagadnienia omawiane $\mathrm{w}$ ramach konwersatorium poświęconego homilii judeochrześcijańskiej i jej nowotestamentalnego zapisu. Podkreślając, że przekazywanie chrześcijańskie opiera się na modelu judaistycznym, Ksiądz Profesor omawiał teksty Nowego Testamentu potwierdzające istnienie homilii synagogalnej, np. Mk 1, 21 (nauczanie Jezusa w synagodze). Pamiętam jego sformułowania: homilia chrześcijańska wyrosła z homilii judajskiej w wymiarze chrystologicznym, lecz w innym rodzaju literackim, Jezus nie szukał nowej metody; chrześcijanie wzięli homilię, lecz nadali jej inny wymiar argumentowania. Ksiądz Chmiel ukazywał ślady homilii judeochrześcijańskiej poza pismami rabinistycznymi w dziełach Filona Aleksandryjskiego czy w księgach apokryficznych. Przedstawiał strukturę homilii rabinistycznych: petihta („otwarcie”) - homilia wychodząca od tekstu Starego Testamentu (np. Dz 17, 3); jelamedenu („niech nas pouczy”) - rozważania typu prawniczego i moralnego powiązane z pytaniem o postępowanie (Dz 22, 1; Mt 12,1-8). Według Księga Profesora odpowiedzi Jezusa na pytania były jakby w formie homilii, która często zbudowana była na antytezie: znieść i wypełnić prawo; mowy w Dziejach Apostolskich opierały się na schematach greckich - akcenty hellenistyczne można dostrzec w Dz 2. Ksiądz Profesor analizował styl homilii synagogalnej: myślenie kilkupłaszczyznowe i wieloznaczność wypowiedzi. Podkreślał, że żyd nie mógł dać nowego rozwiązania, bo nie było go w Torze, a Jezus głosił homilie synagogalne w nowy sposób, wychodził poza krąg Prawa, opierając się na Starym Testamencie.

Ksiądz profesor Jerzy Chmiel był człowiekiem niezwykłym. Promieniowała od niego energia twórczości, jakieś mistyczne odczytanie słów Biblii. Posługując się sformułowaniem Brandstaettera, ksiądz profesor Jerzy Chmiel miał „słuch biblijny”, który uczynił go wrażliwym na piękno, głębię i mądrość objawionego słowa. Ten słuch biblijny prowadził go w jego wędrówce do źródeł objawienia. 